\title{
Morphometric and Meristic Variability in Butis koilomatodon (Gobiiformes: Eleotridae) in Estuarine and Coastal Areas of the Mekong Delta
}

\author{
Lam Thi Huyen Tran ${ }^{1,2} \&$ Dinh Minh Quang ${ }^{3}$ \\ ${ }^{1}$ Biotechnology Research and Development Institute, Can Tho University, Can Tho \\ 900000, Vietnam \\ ${ }^{2}$ Faculty of Agriculture and Fishery, University of Cuu Long, Vinh Long 890000, Vietnam \\ ${ }^{3}$ Department of Biology, School of Education, Can Tho University, Can Tho 900000, \\ Vietnam
}

\begin{abstract}
The study aimed to investigate morphometric and meristic variability in the mud sleeper Butis koilomatodon (Bleeker, 1849) in the Mekong Delta. This species is a commercial fish species with a small-size and is mainly distributed in some coastal areas from Tra Vinh to Ca Mau provinces. In the present research, the parameters of morphometry and measurement, including the head length, body depth, eye diameter, distance of the two eyes, and the interrelationships among the morphometric variables, were determined. The results revealed that the total length and weight of the fish changed by sex, season, habitat, and the interaction between the seasons and habitats. Likewise, the meristic criteria were different between males and females, and the dry and wet seasons, but not by their interactions. The growth rate of males was faster than females. The outcomes also showed that the body size of this species was larger in the dry season and the largest fish were found in Duyen Hai and Tra Vinh provinces. The Findings would be useful not only for further effects of environmental factors on morphology but also for comparisons between congeners Butis morphologically.
\end{abstract}

\section{Keywords}

Measurement, meristic criteria, morphometry, the growth rate, the mud sleeper

\section{Introduction}

Morphometric and meristic characters have played a crucial role

Received: June 8, 2020

Accepted: October 28, 2020

Correspondence to dmquang@mku.edu.vn in identifying fish stocks and establishing the evolutionary linkages between ancient and modern fish fauna (Turan, 2004). In fisheries biology, morphometric characteristics have been used to estimate the percentage of fish harvested from length-weight data, determine the effects of environmental improvement, and regulate fisheries 
(Ibáñez-Aguirre et al., 2006). In classification, this information has been useful to classify fish (Nelson et al., 2016) and measure differences and relationships among congeners (Turan et al., 2006). Besides, they have also been used to study variations due to environmental factors (Hossain et al., 2009). Sandlund et al. (1992) noted that the morphological characteristics of fish populations like body coloration, meristic characteristics, growth, size, and age at sexual maturity could differ in different habitats. Morphological characteristics may be the result of evolution over time to adapt to natural selective pressures, genetic modifications, food availability, habitat competition, or even simple coincidence (Burns \& Sidlauskas, 2019; Thacker \& Gkenas, 2019).

Butis koilomatodon (Bleeker, 1849) belongs to the family Eleotridae, order Gobiiformes, and is found along the Indo-Western Pacific region as a native species (Dawson, 1973). However, it is considered an invasive species in northeastern Brazil, competing with other native gobies for food and habitat (Macieira et al., 2012; GuimarãEs et al., 2017). This goby is a carnivore, and its main food items are crustaceans and small fish (Froese and Pauly, 2000). This mud goby usually dwells in estuaries and mangrove creeks with salinity from $3.8 \%$ to 37.0\%o (Contente et al., 2016). In Vietnam, B. koilomatodon is found in the Mekong Delta (Rainboth, 1996; Tran et al., 2013), especially in coastal areas. Because of its nutritional value, good flavor, and firm texture, the economic value of this fish is relatively high. Nevertheless, recent studies on the morphological characters of $B$. koilomatodon have been fragmented and insufficient (Soares et al., 2012; Contente et al., 2016; GuimarãEs et al., 2017). Hence, this research aims to fill the knowledge gaps about the morphometric and meristic parameters of this species according to gender, season, and regions of several Vietnamese provinces, namely Duyen Hai (Tra Vinh); Cu Lao Dung and Tran De (Soc Trang); Hoa Binh and Dong Hai (Bac Lieu); and Dam Doi (Ca Mau).

\section{Materials and Methods}

\section{Study sites}

Fish samples were collected from 04/2019 to $03 / 2020$ in six different sites along estuarine regions, namely Duyen Hai, Tra Vinh (DHTV, 9॰41'18.6"N 106³0'35.8"E); Cu Lao Dung (CLDST, 9³3'20.1"N 106¹6'57.9"E); Tran De, Soc Trang (TDST, 9 ${ }^{\circ} 29^{\prime} 26.8^{\prime \prime} \mathrm{N} 106^{\circ} 11^{\prime} 58.5^{\prime \prime E}$ ); Hoa Binh, Bac Lieu (HBBL, $9^{\circ} 12^{\prime} 24.8^{\prime \prime} \mathrm{N}$ $105^{\circ} 42^{\prime} 54.9^{\prime \prime}$ ); Dong Hai, Bac Lieu (DHBL, $\left.9^{\circ} 06^{\prime} 03.2^{\prime \prime} \mathrm{N} 105^{\circ} 29^{\prime} 49.1^{\prime \prime E}\right)$; and Dam Doi, Ca Mau (DDCM, $\left.8^{\circ} 58^{\prime} 17.5^{\prime \prime N} \quad 105^{\circ} 22^{\prime} 51.8^{\prime \prime} \mathrm{E}\right)$ (Figure 1). The dominant sources of vegetation were Avicennia marina and Sonneratia caseolaris in these places. Moreover, these locations had large mudflats and semi-diurnal tides making them ideal habitats for some aquatic animals. As well as in other subtropical areas, the typical climate is an annual monsoon with two seasons: the dry season (from January to May) with very little rainfall and the rainy season (from June to December) with a monthly rainfall of $400 \mathrm{~mm}$. The average annual temperature is about $27^{\circ} \mathrm{C}$ (Le et al., 2006). Some of the abiotic factors collected by the present work were water temperature, $\mathrm{pH}$ (by a thermometer-Model: HI98127), and salinity (by a refractometerModel: 950.0100 PPT-ATC) in each of the six habitats.

\section{Fish collection}

Fish collection was conducted monthly during 2019 by dragging bottom trawl nets. The nets were $5 \mathrm{~m}$ long with $1.5 \mathrm{~cm}$ mesh size in the cod-end and $2.5 \mathrm{~cm}$ in the mouth. When the tide was the highest, trawl nets were set up near the edge of the mangrove forest. After 2-3 $\mathrm{h}$ as the tide receded, the nets were pulled up to collect the fish. The collected specimens were preserved in $5.0 \%$ formalin and classified based on their external morphology according to the report of Tran et al. (2013) in the laboratory. The fish sexes were differentiated based on the morphology of urogenital papilla, e.g., round in females and narrow in males (Dinh et al., 2020). In the zoological laboratory, B. koilomatodon specimens were measured for total length (nearest $0.1 \mathrm{~cm}$ ) and weighted (nearest $0.01 \mathrm{~g}$ ). Some of the morphometric and meristic data were taken according to Murdy (1989) and Daud et al. (2005) (Figure 2). Ratios such as head length/ 


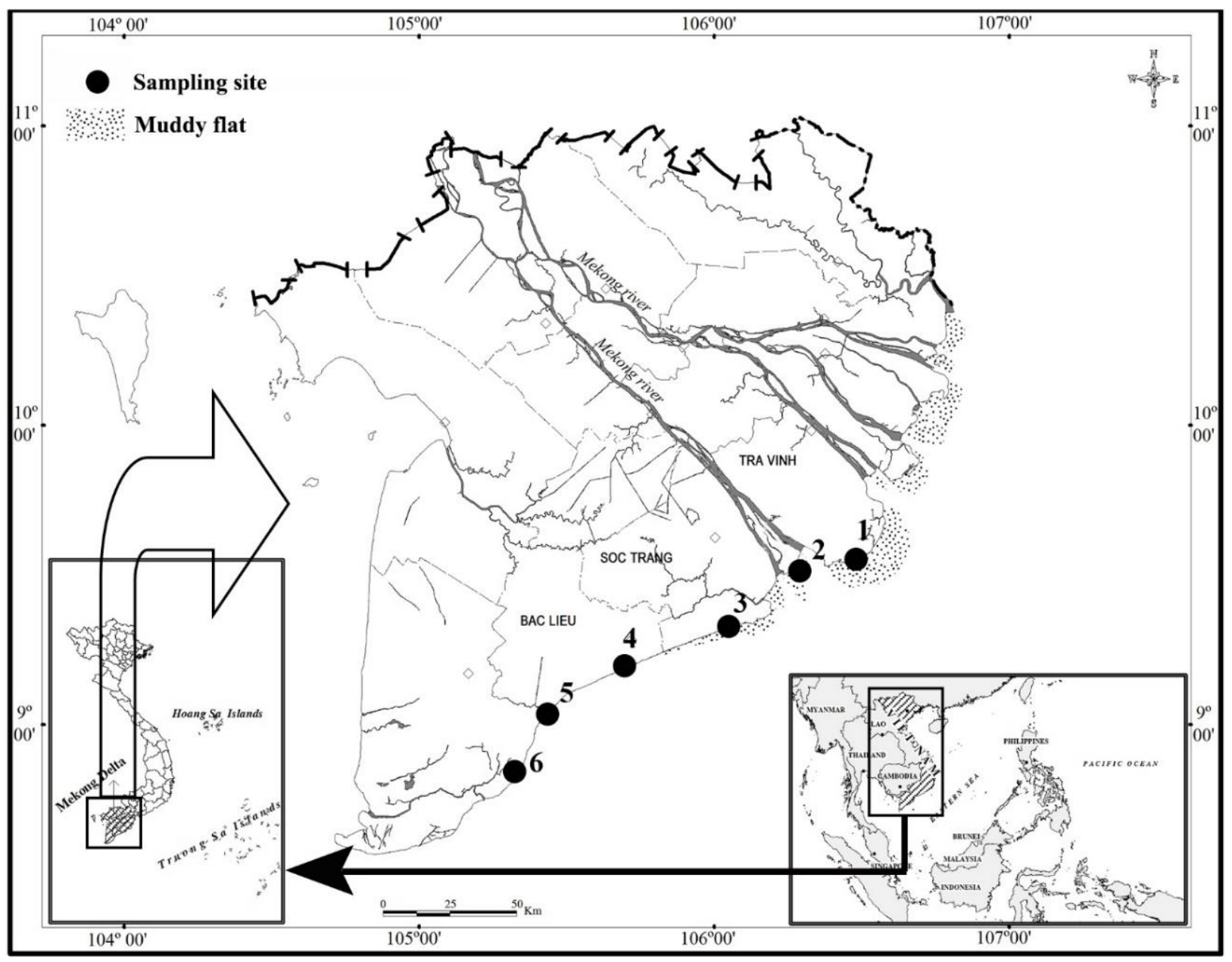

Note: $\because$ Sampling area; 1: Duyen Hai, Tra Vinh, 2: Cu Lao Dung, Soc Trang, 3: Tran De, Soc Trang, 4: Hoa Binh, Bac Lieu, 5: Dong Hai, Bac Lieu, and 6: Dam Doi, Ca Mau.

Figure 1. Sampling locations map in the Mekong Delta

standard length (HL/SL), body depth/standard length (BD/SL), eye diameter/head length (ED/HL), and distance of two eyes/head length (DE/HL) were also calculated. In parallel, meristic data such as the number of scales along the body, circumferential scales, and the number of rays in first and second dorsal fins were taken.

\section{Data analysis}

The t-test was used to examine the variation in total length (TL) and weight (W) between genders and seasons. When the TL and W significantly varied among the six sites, one-way ANOVA was then used to test if the differences were significant. Two-way ANOVA was also used to test the interaction of three variables, viz. gender $\times$ season, gender $\times$ site, and season $\times$ site. In addition, one-way ANOVA was applied to test the differences of morphometric and meristic parameters (head length/standard length (HL/SL), body depth/standard length (BD/SL), eye diameter/head length (ED/HL), and distance of two eyes/head length (DE/HL)). SPSS software v.21 was used to analyze the data at a $5 \%$ significance level for all the tests.

\section{Results and Discussion}

\section{Vegetation and water environment parameters}

There were many kinds of mangrove vegetation in the sampled sites such as Nypa fruticans Wurmb, Avicennia marna (Forssk.) Vierh., Sonneratia caseolaris (L.) A. Engl., Bruguiera gymnorrhiza (L.) Savigny, Rhizophora apiculata Blume, and Acanthus ebracteatus Vahl. The dominating flora in $\mathrm{Cu}$ 


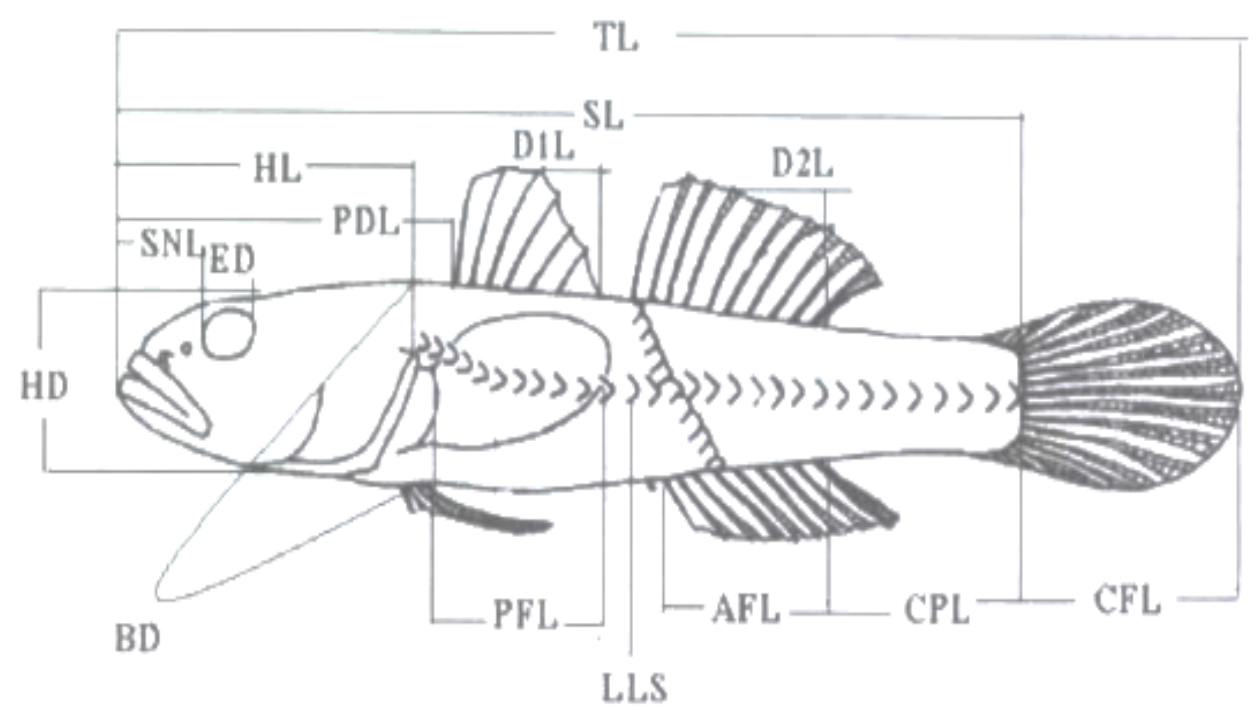

Note: Total length (TL), Standard length (SL), Head length (HL), Body depth (BD), Eye diameter (ED), and Distance of two eyes (DE) (Daud et al., 2005).

Figure 2. Morphometric characters used for B. koilomatodon in the present study

Table 1. Water parameters among the sampling sites (average \pm standard deviation)

\begin{tabular}{cccc}
\hline Sampling sites & Temperature $\left({ }^{\circ} \mathrm{C}\right)$ & $\mathrm{pH}$ & Salinity $(\%)$ \\
\hline Duyen Hai & $30.03 \pm 2.48$ & $7.92 \pm 0.08$ & $20.60 \pm 9.29$ \\
Tran De & $28.38 \pm 1.65$ & $7.84 \pm 0.15$ & $22.60 \pm 9.76$ \\
Cu Lao Dung & $29.20 \pm 1.06$ & $7.75 \pm 0.10$ & $18.00 \pm 8.04$ \\
Hoa Binh & $28.15 \pm 1.68$ & $7.73 \pm 0.16$ & $24.83 \pm 3.92$ \\
Dong Hai & $27.85 \pm 2.61$ & $7.78 \pm 0.25$ & $28.67 \pm 4.13$ \\
Dam Doi & $28.70 \pm 2.34$ & $7.82 \pm 0.08$ & $26.33 \pm 5.32$ \\
\hline
\end{tabular}

Lao Dung and Tran De (Soc Trang province) was Avicennia marna while Bruguiera gymnorrhiza was predominant in Hoa Binh and Dong Hai (Bac Lieu province). These two kinds of mangroves were also found mainly in Dam Doi, Ca Mau province. In Duyen Hai, Sonneratia caseolaris dominated.

The average values of temperature, $\mathrm{pH}$, and salinity in the six sites are presented in Table 1. The results showed that there were no remarkable differences in the average temperature and $\mathrm{pH}$ values among the six studied habitats. The temperature ranged from 27.85 to $30.03^{\circ} \mathrm{C}$, and $\mathrm{pH}$ maintained at about 7.0 to 8.0. On the other hand, significant changes in salinity were recorded. The lowest salinity value was in $\mathrm{Cu}$ Lao Dung (18.00\%), and the highest was in Dong Hai $(28.67 \%$ ). Among the six sampling sites, only $\mathrm{Cu}$ Lao Dung was an island and this geographic feature is a possible reason for the difference in the salinity parameter.

\section{External morphological variation}

The external characteristics of $B$. koilomatodon were the same as the descriptions of Macieira et al. (2012) and GuimarãEs et al. (2017) of this species along the Brazilian coast, and of Yokoo et al. (2006) in a Thai mangrove estuary. The body coloration of live and fresh specimens was pale beige to greyish beige, with four to seven dark-brown diffuse bands (the last band at the caudal peduncle) (Figure 3). The first and second brown dorsal fins were 8-9 rays and 5-6 rays, respectively. The number of scales along the body was from 26 to 28 , and the number of half-circumferential scales was 12 . The number of bands on the body (four to seven) and serrated snout were the important characters 


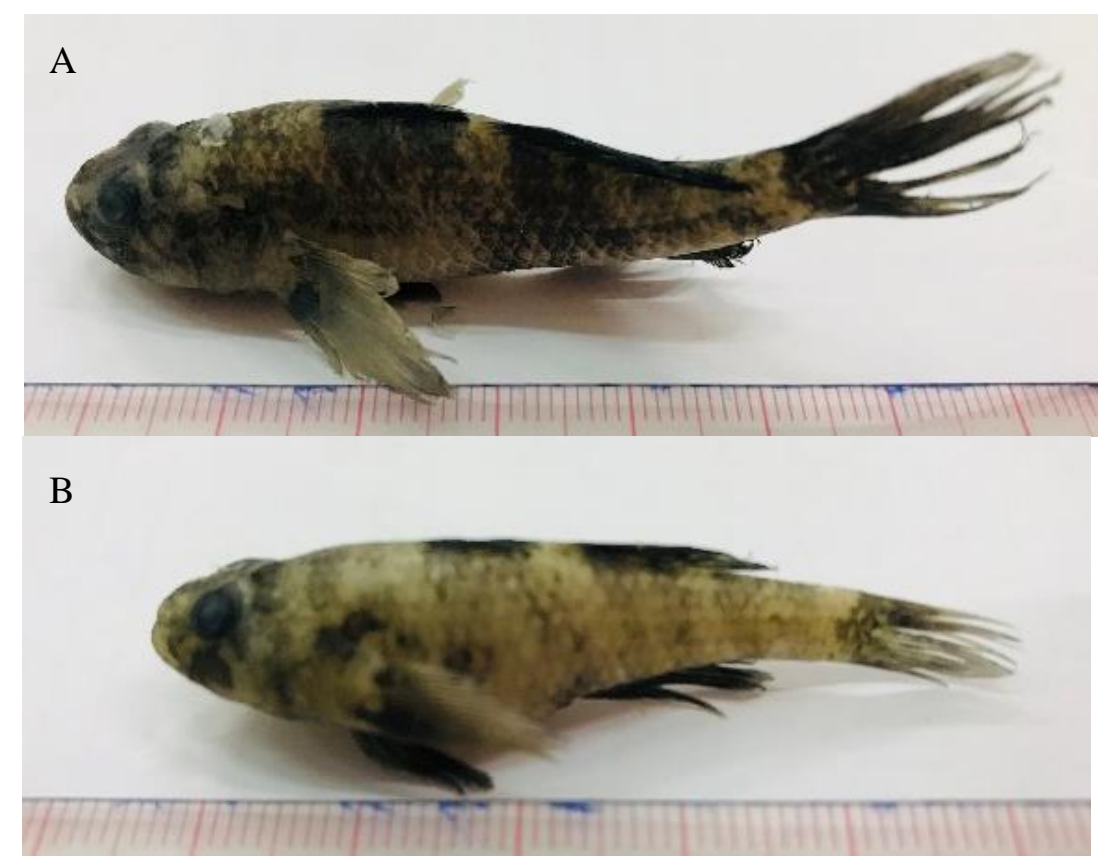

Figure 3. Specimens of Butis koilomatodon (A: Male and B: Female) collected in coastal areas in the Mekong Delta

Table 2. The changes in total length and body weight of $B$. koilomatodon specimens according to gender and season.

\begin{tabular}{lccc}
\hline Morphometry & Category & Number of fish & Mean \pm SE \\
\hline \multirow{2}{*}{ Fish total length $(\mathrm{cm})$} & Male & 768 & $7.35 \pm 0.04$ \\
& Female & 295 & $6.54 \pm 0.05$ \\
Fish body weight $(\mathrm{g})$ & Male & 768 & $6.01 \pm 0.09$ \\
& Female & 295 & $4.44 \pm 0.11$ \\
Fish total length (cm) & Dry & 461 & $7.39 \pm 0.05$ \\
& Wet & 602 & $6.92 \pm 0.04$ \\
Fish body weight $(\mathrm{g})$ & Dry & 461 & $6.05 \pm 0.13$ \\
& Wet & 602 & $5.21 \pm 0.09$ \\
\hline
\end{tabular}

to differentiate B. koilomaton from Butis congeners (Yokoo et al., 2006).

The variable comparison of total length (TL) and body weight (W) of the 1,063 studied specimens of B. koilomatodon (295 females and 768 males) is presented in Table 2. The results of the t-test showed the average weight and the total length of males were significantly higher than in females (t-test, $t_{W s}=10.930, t_{T L s}=12.734$, $\mathrm{P}<0.01$ ). Additionally, the TL and $\mathrm{W}$ average values were higher in the dry season than the wet season at the significance level of $1 \%$ (t-test, $t_{W s}$ $\left.=5.459, t_{T L S}=7.450, P<0.01\right)$.

The results indicated that males grew more quickly than females. Observations have shown that the larger males are, the more successful they are in competing for a nest site and attracting females to their nest. If a male was unfortunate in failing to build a nest, another male would replace his role quickly (Lindström \& Hellström, 1993). The males were larger than females, which was corroborated by the proposed results of Soares et al. (2012) who reported lengths of $4.75 \pm 0.35 \mathrm{~cm}$ and $4.40 \pm 0.76 \mathrm{~cm}$ for males and females, respectively. A similar result was described in two-spotted gobies (Houde, 2001). Thus, body size may be a criterion for allowing active mate choice.

The TLs and Ws in the dry season were also significantly greater than in the wet season. The seasonal change of environmental factors such as temperature, rainfall, salinity, and $\mathrm{pH}$ were the main causes that influenced the body size of 
these specimens. In contrast, a study conducted in Pakistan revealed that gobies were not affected by the seasons (Mahmood et al., 2012; Dinh et al., 2016a). The TLs and Ws of some gobiid species co-living in the Mekong Delta were higher in the wet season than in dry season, for instance for Parapocryptes serperaster (Richardson, 1846) (Dinh et al., 2016b), Trypauchen vagina (Bloch \& Schneider, 1801) (Dinh, 2016), Boleophthalmus boddarti (Pallas, 1770) (Dinh, 2017a), and Stigmatogobius pleurostigma (Bleeker, 1849) (Dinh, 2017b). Typically, the dry season is harsher than the rainy season because of less rainfall and saline intrusion. This result suggested that $B$. koilomatodon could reach the highest TL and W values in the dry season.

In Figure 4, the average weight values were different by habitat, with the highest value in DHTV $(6.92 \pm 0.28 \mathrm{~g})$ and lowest value in TDST $(4.12 \pm 0.26 \mathrm{~g})$ (one-way ANOVA, $F=17.737$, $P<0.01)$. Similarly, the TLs were also influenced by the spatial variation with the highest values in DHTV and HBBL $(7.73 \pm 0.09 \mathrm{~cm} ; 7.41 \pm 0.05$ $\mathrm{cm}$, respectively) and the lowest values in the remaining four sampling sites CLDST, TDST, $\operatorname{DHBL}$, and $\operatorname{DDCM}(F=20.199, P<0.01$, Figure 5). These data suggest that the TLs and Ws of this species change by habitat and reached the highest values in the DHTV habitat.

The Ws did not depend on the interaction of gender $\times$ season (Figure 6) (two-way ANOVA, $F=0.056, P>0.05)$ or gender $\times$ site $(F=1.223$, $P>0.05)$ but were affected by season $\times$ site $(F=$ $5.755, P<0.01$, Figure 7). Likely, the changes in the TLs of $B$. koilomatodon did not depend on the interaction of gender $\times$ season $(F=0.145, P>$ 0.05 , Figure 8) or gender $\times$ site $(F=1.136, P>$ 0.01 ) but were impacted by the interaction between season and site $(F=5.214, P<0.01$, Figure 9). This revealed that mud sleepers have different growth depending on the different kinds of habitats and seasons.

\section{Meristic variation}

Table 3 shows the meristic parameters ED, $\mathrm{DE}, \mathrm{BD}, \mathrm{HL}, \mathrm{HL} / \mathrm{TL}$, and BD/TL between males and females of the mudsleeper B. koilomatodon. The results revealed that some of the factors depended on the gender. For example, BD, HL, and $\mathrm{DE} / \mathrm{HL}$ had significant differences between females and males at the $5.0 \%$ level (one-way ANOVA, $P<0.05)$. The reason for these differences was that the body size of males was more massive than females. There were no statistical differences in the other parameters (ANOVA, $P>0.05$ ).

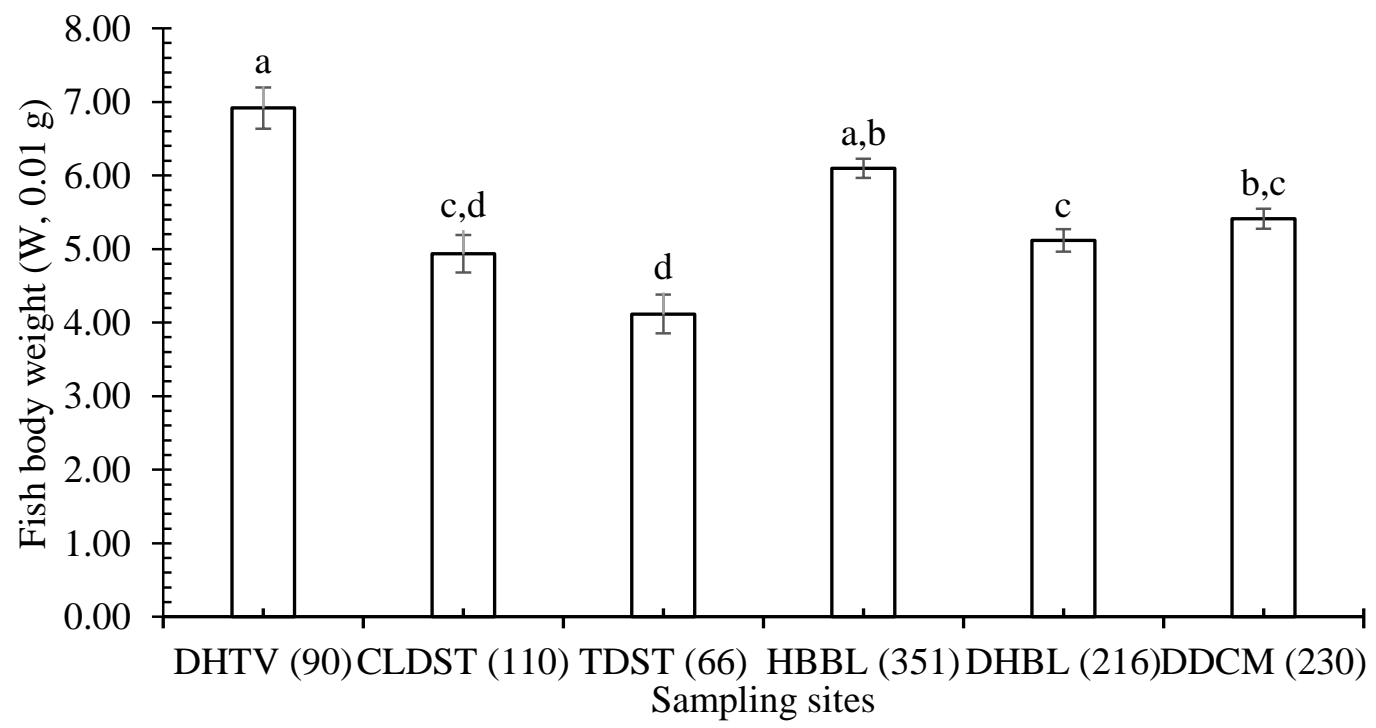

Note: DHTV: Duyen Hai, Tra Vinh; CLDST: Cu Lao Dung, Soc Trang; TDST: Tran De, Soc Trang; HBBL: Hoa Binh, Bac Lieu; DHBL: Dong Hai, Bac Lieu and DDCM: Dam Doi, Ca Mau; number in parentheses: number of fish collected at each site; the vertical bar is the standard error of the mean; different letters ( $a, b, c$, and d) represent the significant differences.

Figure 4. The variation in body weight at the six sampling sites 


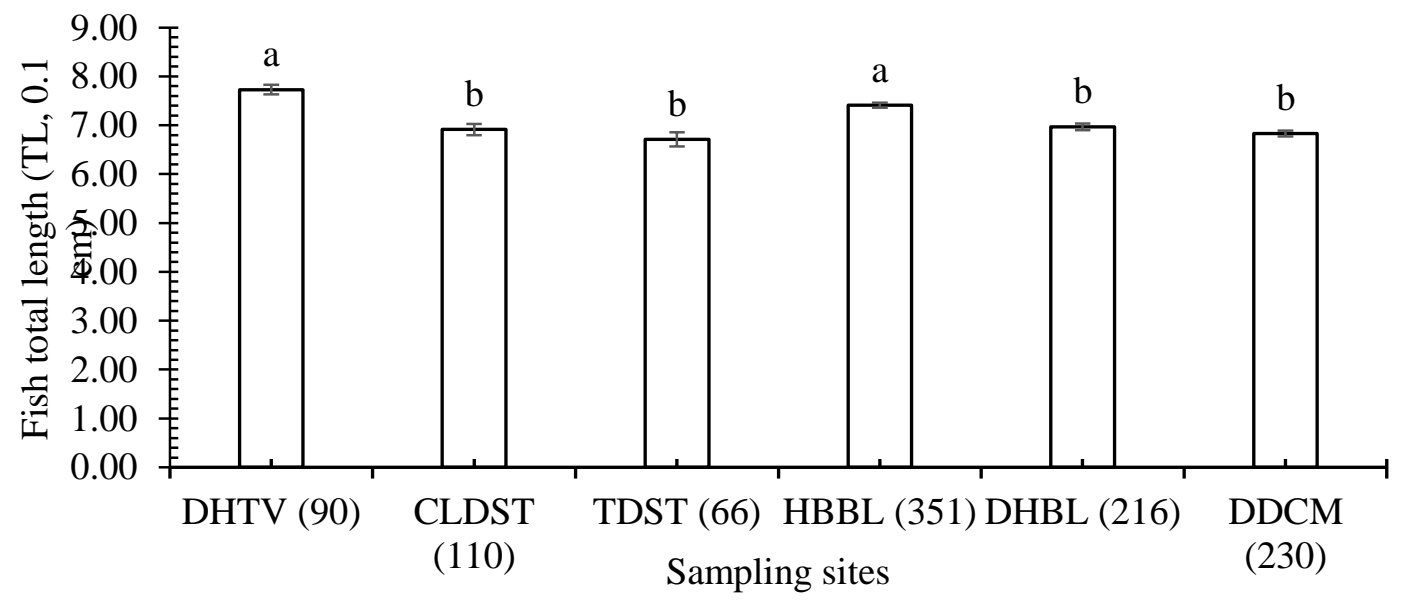

Note: DHTV: Duyen Hai, Tra Vinh; CLDST: Cu Lao Dung, Soc Trang; TDST: Tran De, Soc Trang; HBBL: Hoa Binh, Bac Lieu; DHBL: Dong Hai, Bac Lieu, and DDCM: Dam Doi, Ca Mau; number in parentheses: number of fish collected at each site; the vertical bar is the standard error of the mean; different letters ( $a$ and $b$ ) represent the significant differences.

Figure 5. The variation in fish total length at the six sampling sites

\section{$\square$ Female $\square$ Male}

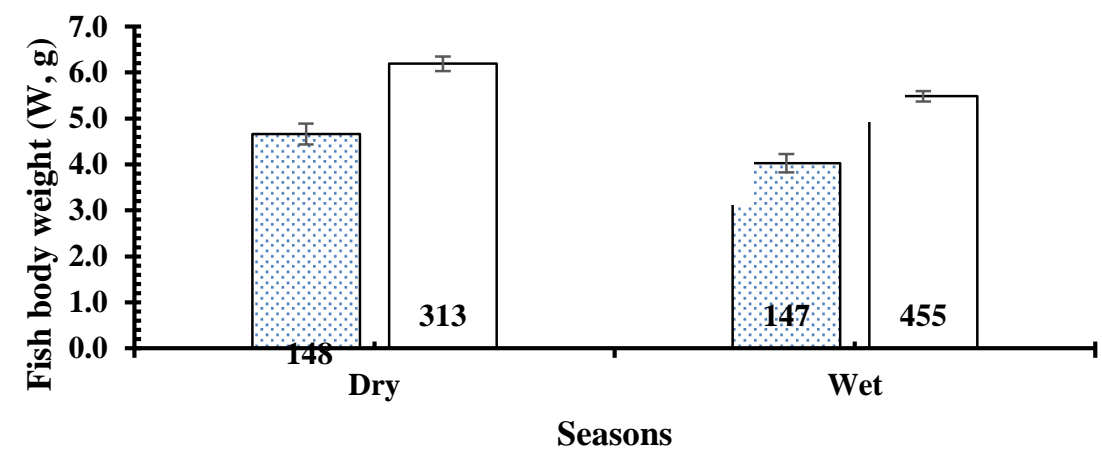

Note: Number in each column: number of fish collected in each season; the vertical bar is the standard error of the mean; different letters ( $a$ and $b$ ) represent the significant differences.

Figure 6 . The influence of season $\times$ gender on the variation of fish body weight

$\square$ Dry $\square$ Wet

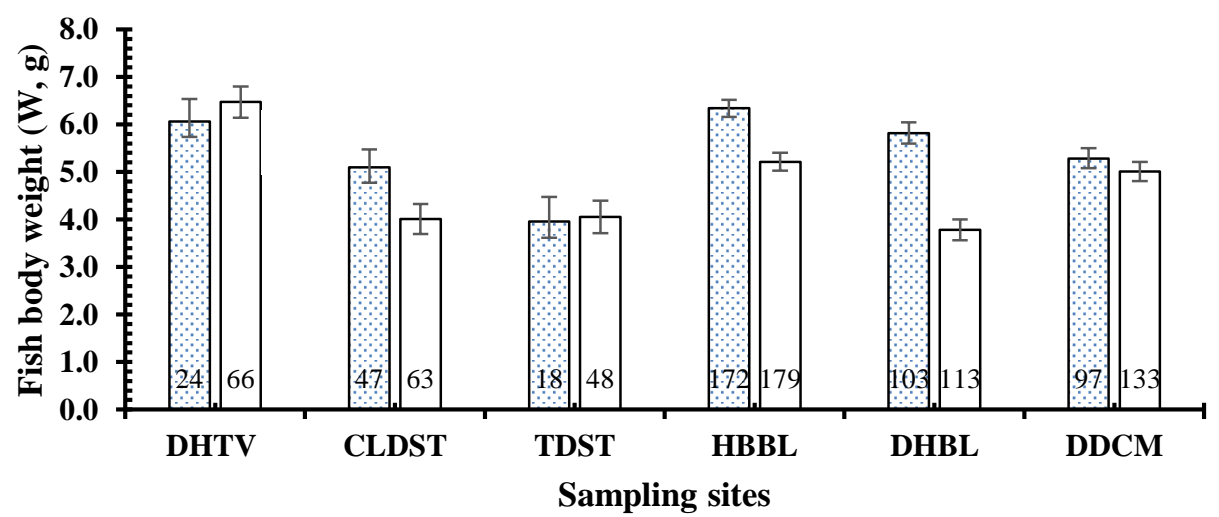

Note: DHTV: Duyen Hai, Tra Vinh; CLDST: Cu Lao Dung, Soc Trang; TDST: Tran De, Soc Trang; HBBL: Hoa Binh, Bac Lieu; DHBL: Dong Hai, Bac Lieu, and DDCM: Dam Doi, Ca Mau; the number in each column: number of fish collected at each site; the vertical bar is the standard error of the mean; different letters $(a, b$, and $c)$ represent the significant differences.

Figure 7. The influence of season $\times$ site on the variation of fish body weight 
$๑$ Female $\square$ Male

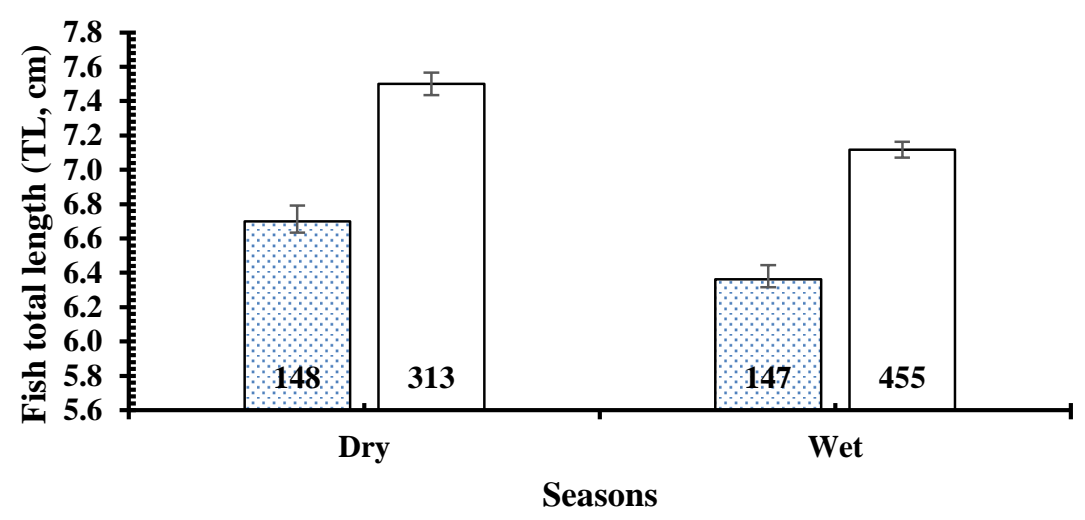

Note: Number in each column: number of fish collected in each season; the vertical bar is the standard error of the mean; different letters ( $a$ and $b$ ) represent the significant differences.

Figure 8 . The influence of season $\times$ gender on the variation of fish total length

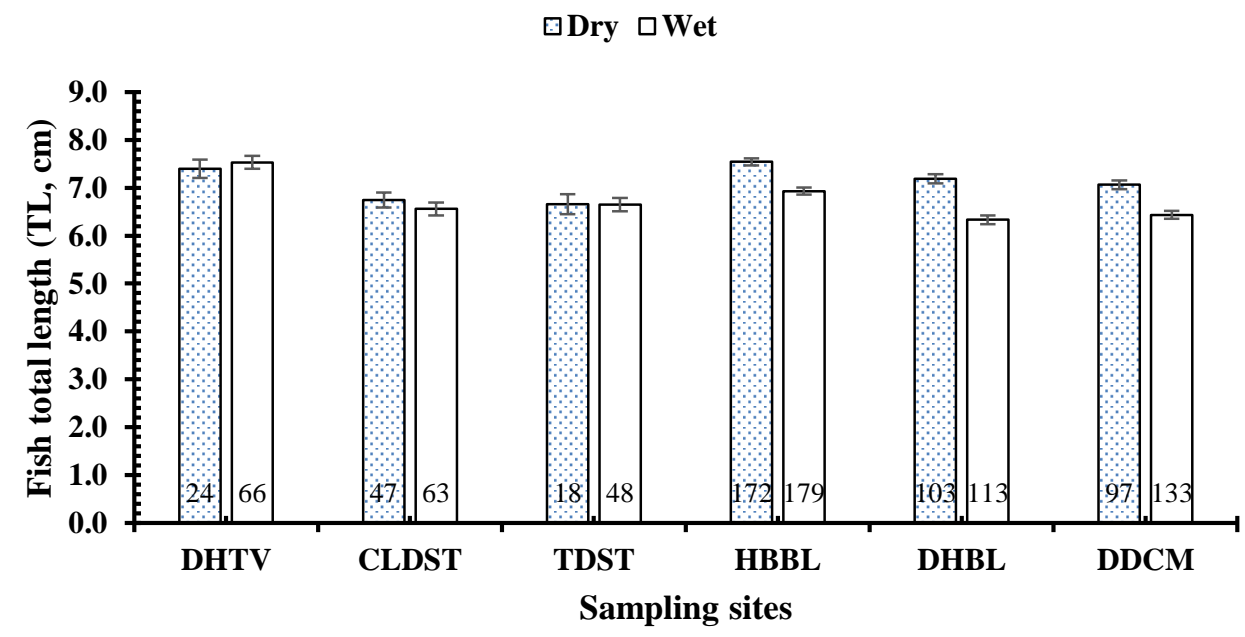

Note: DHTV: Duyen Hai, Tra Vinh; CLDST: Cu Lao Dung, Soc Trang; TDST: Tran De, Soc Trang; HBBL: Hoa Binh, Bac Lieu; DHBL: Dong Hai, Bac Lieu, and DDCM: Dam Doi, Ca Mau; the number in each column: number of fish collected at each site; the vertical bar is the standard error of the mean; different letters $(a, b$ and $c)$ represent the significant differences.

Figure 9. The influence of season $\times$ site on the variation of fish body weight

Table 4 reveals the differences of the meristic parameters between the dry and wet seasons. The season factor had more of an effect than gender on all the criteria except $\mathrm{BD}, \mathrm{BD} / \mathrm{TL}$, and HL/TL (one-way ANOVA, $P>0.05$ ). The HL/TL ratio of $B$. koilomatodon was independent of all three interactions consisting of gender $x$ season, gender $\times$ site, and season $\times$ site (two-way ANOVA, $F_{\text {GenxSea }}=0.536, F_{\text {GenxSite }}=0.556$, $\left.F_{\text {SeaxSite }}=0.700, P>0.05\right)$. A similar result was also found for the BD/TL meristic parameter. The other parameters did not change by the interactions of gender $\times$ season, gender $\times$ site, and season $\times$ site at a significance level of $5 \%$ $\left(F_{\text {GenxSea }}=4.311, F_{\text {GenxSite }}=3.161, F_{\text {SeaxSite }}=\right.$ $14.134, P>0.05)$. Particularly, the DE/HL ratio was only affected by season $\times$ site $\left(F_{\text {SeaxSite }}=\right.$ 13.815, $P<0.05$ ). Last but not least, ED/HL was impacted by season $\mathrm{x}$ site plus the gender $\mathrm{x}$ site interaction $\left(F_{\text {GenxSite }}=3.719, F_{\text {SeaxSite }}=8.941, P<\right.$ $0.05)$. The results suggested that sexes, seasons, habitats, and the interaction between them did not have a clear affect on the meristic criteria of Butis koilomatodon. Similar results 
were found in Periophthalmodon septemradiatus (Dinh et al., 2018) and in Glossogobius Sparsipapillus (Nguyen et al., 2020), two goby species that co-habitat with B. koilomatodon in the Mekong delta.

\section{Conclusions}

In this research, the specimens of Butis koilomatodon expressed differences in morphometric and meristic criteria according to

Table 3. The variation in meristic parameters of $B$. koilomatodon between genders

\begin{tabular}{|c|c|c|c|c|c|c|}
\hline Morphometric parameter & Gender & Number of fish & Mean & Standard deviation & $\mathrm{t}$ & $P$ \\
\hline \multirow{2}{*}{ ED } & Female & 295 & 0.34 & 0.05 & \multirow{2}{*}{5.16} & \multirow{2}{*}{0.53} \\
\hline & Male & 768 & 0.36 & 0.05 & & \\
\hline \multirow{2}{*}{ DE } & Female & 295 & 0.31 & 0.08 & \multirow{2}{*}{3.73} & \multirow{2}{*}{0.73} \\
\hline & Male & 768 & 0.33 & 0.08 & & \\
\hline \multirow[t]{2}{*}{$\mathrm{BD}$} & Female & 295 & 1.28 & 0.23 & \multirow[t]{2}{*}{7.62} & \multirow[t]{2}{*}{0.01} \\
\hline & Male & 768 & 1.41 & 0.27 & & \\
\hline \multirow{2}{*}{$\mathrm{HL}$} & Female & 295 & 1.68 & 0.22 & \multirow{2}{*}{11.76} & \multirow{2}{*}{0.005} \\
\hline & Male & 768 & 1.86 & 0.26 & & \\
\hline \multirow{2}{*}{ HL/TL } & Female & 295 & 31.89 & 2.59 & \multirow{2}{*}{1.24} & \multirow{2}{*}{0.33} \\
\hline & Male & 768 & 31.89 & 2.42 & & \\
\hline \multirow{2}{*}{$\mathrm{BD} / \mathrm{TL}$} & Female & 295 & 24.19 & 2.72 & \multirow{2}{*}{0.02} & \multirow{2}{*}{0.85} \\
\hline & Male & 768 & 23.97 & 2.63 & & \\
\hline \multirow{2}{*}{$\mathrm{ED} / \mathrm{HL}$} & Female & 295 & 27.35 & 5.41 & \multirow{2}{*}{2.95} & \multirow{2}{*}{0.08} \\
\hline & Male & 768 & 26.31 & 5.07 & & \\
\hline \multirow{2}{*}{$\mathrm{DE} / \mathrm{HL}$} & Female & 295 & 24.11 & 6.24 & \multirow{2}{*}{1.55} & \multirow{2}{*}{0.001} \\
\hline & Male & 768 & 23.47 & 5.49 & & \\
\hline
\end{tabular}

Table 4. The variation in meristic parameters of $B$. koilomatodon between seasons

\begin{tabular}{|c|c|c|c|c|c|c|}
\hline Morphometric parameter & Season & Number of fish & Mean & $\begin{array}{l}\text { Standard } \\
\text { deviation }\end{array}$ & $\mathrm{t}$ & $P$ \\
\hline \multirow{2}{*}{ ED } & Dry & 461 & 0.35 & 0.06 & \multirow{2}{*}{0.66} & \multirow{2}{*}{0.00} \\
\hline & Wet & 602 & 0.36 & 0.05 & & \\
\hline \multirow{2}{*}{$\mathrm{DE}$} & Dry & 461 & 0.34 & 0.09 & \multirow{2}{*}{6.01} & \multirow{2}{*}{0.00} \\
\hline & Wet & 602 & 0.31 & 0.07 & & \\
\hline \multirow{2}{*}{$\mathrm{BD}$} & Dry & 461 & 1.43 & 0.27 & \multirow{2}{*}{6.00} & \multirow{2}{*}{0.08} \\
\hline & Wet & 602 & 1.33 & 0.25 & & \\
\hline \multirow{2}{*}{$\mathrm{HL}$} & Dry & 461 & 1.84 & 0.29 & \multirow{2}{*}{2.74} & \multirow{2}{*}{0.00} \\
\hline & Wet & 602 & 1.79 & 0.24 & & \\
\hline \multirow{2}{*}{$\mathrm{HL} / \mathrm{TL}$} & Dry & 461 & 31.44 & 2.43 & \multirow{2}{*}{5.25} & \multirow{2}{*}{0.22} \\
\hline & Wet & 602 & 32.23 & 2.44 & & \\
\hline \multirow{2}{*}{$\mathrm{BD} / \mathrm{TL}$} & Dry & 461 & 24.35 & 2.75 & \multirow{2}{*}{3.44} & \multirow{2}{*}{0.81} \\
\hline & Wet & 602 & 23.79 & 2.56 & & \\
\hline \multirow{2}{*}{$\mathrm{ED} / \mathrm{HL}$} & Dry & 461 & 25.39 & 4.73 & \multirow{2}{*}{6.85} & \multirow{2}{*}{0.01} \\
\hline & Wet & 602 & 27.52 & 5.33 & & \\
\hline \multirow{2}{*}{$\mathrm{DE} / \mathrm{HL}$} & Dry & 461 & 23.95 & 6.09 & \multirow{2}{*}{1.48} & \multirow{2}{*}{0.00} \\
\hline & Wet & 602 & 23.41 & 5.41 & & \\
\hline
\end{tabular}


genders, sites, and seasons as well as the interactions between them. The data indicated that this species reached the highest values of body size in the dry season. In addition, the highest values of its body size were recorded in DHTV. These results would provide useful information for further studies about the influence of food availability and geographical environment on the morphological characteristics of this mud sleeper.

\section{Acknowledgements}

We are grateful to the Ministry of Education and Training for funding support (Project No.: B2019-TCT-02), and Nguyen Thi Nha Y, Nguyen Huu Duc Ton, Nguyen Thi Thuy Hien, Tran Chi Canh, and Dang Hoa Thao for assisting in fish collection and data analysis.

\section{References}

Burns M. D. \& Sidlauskas B. L. (2019). Ancient and contingent body shape diversification in a hyperdiverse continental fish radiation. Evolution. 73: 569-587.

Contente R. F., Brenha-Nunes M. R., Siliprandi C. C., Lamas R. A. \& Conversani V. R. (2016). A new record of the non-native fish species Butis koilomatodon (Bleeker 1849) (Teleostei: Eleotridae) for southeastern Brazil. Biotemas. 29: 113-118.

Daud S. K., Mohammadi M., Siraj S. S. \& Zakaria M. P. (2005). Morphometric analysis of Malaysian oxudercine goby, Boleophthalmus boddarti (Pallas, 1770). Pertanika Journal of Tropical Agricultural Science. 28: 121-134.

Dawson C. (1973). Occurrence of an exotic eleotrid fish in Panama with discussion of probable origin and mode of introduction. Copeia. 1973(1): 141-144.

Dinh M. Q., Tran T. L. \& Nguyen T. Y. N. (2018). The flexibility of morphometric and meristic measurements of Periophthalmodon septemradiatus (Hamilton, 1822) in Hau river. Journal of Science and Technology. 187: 81-90.

Dinh Q. M. (2016). Growth pattern and body condition of Trypauchen vagina in the Mekong Delta, Vietnam. The Journal of Animal and Plant Sciences. 26: 523-531.

Dinh Q. M. (2017a). Morphometric, growth and condition factor variations of Boleophthalmus boddarti in the Mekong delta, Vietnam. Iranian Journal of Fisheries Sciences. 16: 822-831.

Dinh Q. M. (2017b). Morphometrics and condition factor dynamics of the goby Stigmatogobius pleurostigma (Bleeker 1849) during dry and wet seasons in the
Mekong Delta, Vietnam. Asian Fisheries Sciences. 30: $17-25$.

Dinh Q. M., Qin J. G., Dittmann S. \& Tran D. D. (2016a). Morphometric variation of Parapocryptes serperaster (Gobiidae) in dry and wet seasons in the Mekong Delta, Vietnam. Ichthyological Research. 63: 267-274.

Dinh Q. M., Qin J. G., Dittmann S. \& Tran D. D. (2016b). Reproductive biology of the burrow dwelling goby Parapocryptes serperaster. Ichthyological Research. 63: 324-332.

Dinh Q. M., Tran L. T., Ngo N. C., Pham T. B. \& Nguyen T. T. K. (2020). Reproductive biology of the unique mudskipper Periophthalmodon septemradiatus living from estuary to upstream of the Hau River. Acta Zoologica. 101: 206-217.

Froese R. \& Pauly D. (2000). FishBase a global information system on fishes. FishBase, Makati City, Philippines.

GuimarãEs E. C., Brito P. \& Ottoni F. P. (2017). First record of Butis koilomatodon (Bleeker, 1849)(Gobiiformes: Eleotridae) for the Maranhão state, northeastern Brazil: a case of bioinvasion. Cybium. 41: 299-300.

Hossain M. Y., Ohtomi J., Ahmed Z. F., Ibrahim A. H. M. \& Jasmine S. (2009). Length-weight and morphometric relationships of the Tank goby Glossogobius giuris (Hamilton, 1822) (Perciformes: Gobiidae) in the Ganges of Northwestern Bangladesh. Asian Fisheries Sciences. 22: 961-969.

Houde A. E. (2001). Sex roles, ornaments, and evolutionary explanation. Proceedings of the National Academy of Sciences. 98: 12857-12859.

Ibáñez-Aguirre A. L., Cabral-Solís E., Gallardo-Cabello M. \& Espino-Barr E. (2006). Comparative morphometrics of two populations of Mugil curema (Pisces: Mugilidae) on the Atlantic and Mexican Pacific coasts. Scientia Marina. 70: 139-145.

Le Thong, Nguyen Minh Tue, Nguyen Van Phu, Nguyen Dang Chung, Pham Xuan Hau, Nguyen Thi Son, Hoang Van Chuc, Hoang Phuc Lam, Le Huynh \& Dao Ngoc Canh (2006). Provinces and City in the Mekong Delta. Education Publishing House, Hanoi (in Vietnamese).

Lindström K. \& Hellström M. (1993). Male size and parental care in the sand goby, Pomatoschistus minutus. Ethology Ecology and Evolution. 5: 97-106.

Macieira R., Giarrizzo T., Gasparini J. \& Sazima I. (2012). Geographic expansion of the invasive mud sleeper Butis koilomatodon (Perciformes: Eleotridae) in the western Atlantic Ocean. Journal of Fish Biology. 81: 308-313.

Mahmood K., Ayub Z., Moazzam M. \& Siddiqui G. (2012). Length-weight relationship and condition factor of Ilisha melastoma (Clupeiformes: Pristigasteridae) off Pakistan. Pakistan Journal of Zoology. 44: 71-77.

Murdy E. O. (1989). A taxonomic revision and cladistic 
analysis of the oxudercine gobies (Gobiidae, Oxudercinae). Australian Museum Journal. 11: 93.

Nelson J. S., Grande T. C. \& Wilson M. V. (2016). Fishes of the World. John Wiley \& Sons.

Nguyen T. H. D., Nguyen H. T. T., Tran T. C., Nguyen Y. T. N. \& Dinh Q. M. (2020). Morphometric and meristic variations of Glossogobius sparsipapillus along the coastline in the Mekong Delta, Vietnam, International Journal of Zoology and Animal Biology. 3: $1-9$.

Rainboth W. J. (1996). Fishes of the Cambodian Mekong. FAO, Roma.

Sandlund O. T., Gunnarsson K., Jónasson P. M., Jonsson B., Lindem T., Magnússon K. P., Malmquist H. J., Sigurjónsdóttir H., Skúlason S. \& Snorrason S. S. (1992). The arctic charr Salvelinus alpinus in Thingvallavatn. Oikos. 64: 305-351.

Soares B. E., Ruffeil T. O. B. \& Montag L. d. A. (2012). Occurrence of the non-native sleeper Butis koilomatodon (Bleeker, 1849) (Perciformes: Eleotridae) in the Amazon coastal zone, Brazil. BioInvasions Records. 1: 95-99.
Thacker C. E. \& Gkenas C. (2019). Morphometric convergence among European sand gobies in freshwater (Gobiiformes: Gobionellidae). Ecology and Evolution. 9: 8087-8103.

Tran Dac Dinh, Shibukawa, K., Nguyen Thanh Phuong, Ha Phuoc Hung, Tran Tran Xua Loi, Mai Van Hieu, \& Utsugi K. (2013). "Fishes of Mekong Delta, Vietnam," Can Tho University Publisher, Can Tho (in Vietnamese).

Turan C. (2004). Stock identification of Mediterranean horse mackerel (Trachurus mediterraneus) using morphometric and meristic characters. ICES Journal of Marine Science. 61: 774-781.

Turan C., Oral M., Öztürk B. \& Düzgüneş E. (2006). Morphometric and meristic variation between stocks of Bluefish (Pomatomus saltatrix) in the Black, Marmara, Aegean and northeastern Mediterranean Seas. Fisheries Research. 79: 139-147.

Yokoo T., Kanou K., Moteki M., Kohno H., Tongnunui P. \& Kurokura H. (2006). Juvenile morphology and occurrence patterns of three Butis species (Gobioidei: Eleotridae) in a mangrove estuary, southern Thailand. Ichthyological Research. 53: 330-336. 